\title{
Andean deformation and rift inversion, eastern edge of Cordillera Oriental (Guateque-Medina area), Colombia
}

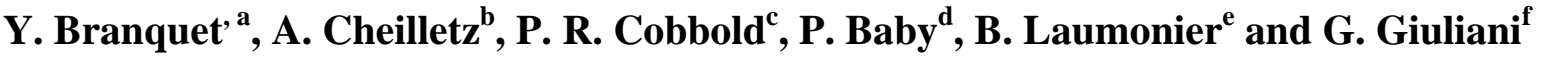 \\ a Institut des Sciences de la Terre d'Orléans, UMR 6113 - CNRS - Université d'Orléans \\ Bâtiment géosciences, BP 6759, 45067, Orléans Cedex 02, France \\ ${ }^{\mathrm{b}}$ Ecole Nationale Supérieure de Géologie (ENSG-INPL) and Centre de, Recherches \\ Pétrographiques et Géochimiques (CRPG-CNRS), BP 20, 54501, Vandœuvre-lès-Nancy \\ Cedex, France \\ c Géosciences-Rennes (UMR6881 du CNRS), Université de Rennes I, 35042, Rennes Cedex, \\ France \\ d Institut de Recherche pour le Développement (IRD), 209-213 rue La, Fayette, 75480, Paris \\ Cedex 10, France \\ e Ecole des Mines, 54042, Nancy, France \\ ${ }^{\mathrm{f}}$ IRD and CRPG-CNRS, France
}

\section{Abstract}

In the Guateque-Medina area, Paleozoic basement and Mesozoic rift basins have been uplifted and exhumed during the Andean orogeny (12 Ma to present). Surface exposures and subsurface data constrain the deformation style and the rift geometry. We have mapped a regional transect and restored a cross section. We have also reconciled existing stratigraphic data, from cordillera, foothills and foreland basin, and have added new data of our own. In Early Cretaceous shales, there is evidence for fault-controlled sedimentation. A brecciated evaporitic layer, which is locally emerald bearing, has acted as a regional detachment. The underlying basement, composed of Paleozoic sediments, crops out as the Quetame Massif. It was uplifted during the Andean orogeny on a series of high-angle reverse faults. The main SE-verging Tesalia fault has resulted from Andean reactivation of an Early Cretaceous normal fault, which bounded a half-rift. A series of NW-verging back-thrusts may have resulted from Andean reactivation of Paleozoic faults. Between the back-thrusts and the Tesalia fault is a basement pop-up. It may be part of a flower structure, because components of right-lateral slip have been identified. These are attributed to eastward subduction of the Nazca plate beneath South America. In general, the style and timing of Andean deformation in the Guateque-Medina area are compatible with the plate tectonic setting of the northern Andes.

Author Keywords: Andean deformation; Rift inversion; Colombia; Cordillera Oriental; Guateque-Medina area 


\section{Introduction}

This paper describes the structural geology of the eastern edge of the Cordillera Oriental (CO) and adjacent Llanos foothills, which produce much of the oil in Colombia. The CO resulted from tectonic inversion of a Mesozoic rift basin during the Andean orogenic phase, which lasted from the middle Miocene to the present (Colletta et al., 1990). Compressional reactivation of Early Cretaceous rift-bounding normal faults features on all modern crosssections of the CO ( Colletta; Dengo; Cooper and Roeder), particularly in the area of the Cusiana oil field ( Fig. 1A). At this latitude, Andean deformation at the edge of the CO has resulted from NW-SE compression and is characterized by SE-verging NE-trending thrust faults (Cooper et al., 1995). These faults are either reactivated Early Cretaceous normal faults that involve basement (e.g. the Guaicáramo and Cusiana faults) or thin-skinned faults with associated duplexes and fault-related folds (e.g. the Yopal fault). The main frontal thrust (Guaicáramo fault) was originally an extensional master fault at the eastern edge of a Mesozoic rift system (Fig. 1B). As it now truncates detachments, this fault must have formed out of sequence. Northward, the thin-skinned Yopal fault overrides the Cusiana fault.

For areas further south, reactivation of major faults (e.g. the Tesalia, Altamira and Algeciras faults on Fig. 1) has been less well documented. Is the structural pattern similar to that described to the north in the Cusiana-Yopal area?

For three reasons, the Guateque-Medina area (GMA, Fig. 1) is a key area for documenting inversion of Mesozoic rifts.

1. The Quetame Massif, which has a core of Paleozoic basement, has been uplifted on thickskinned thrusts, so that Mesozoic rifts and their substrate are visible at the surface.

2. The style and timing of Andean deformation are constrained by seismic profiles and wells in the foothills.

3. According to earthquake and fault-slip data (Taboada et al., 2000), the current tectonic context is one of right-lateral wrenching to the south of the GMA (e.g. along the Altamira and Algeciras faults, Fig. 1) and of crustal thickening to the north of the GMA (e.g. along the Guaicáramo fault in the Cusiana-Yopal area).

Rowan and Linares (2000) interpreted the northern edge of the Quetame Massif as the offset corner of a tilted rift shoulder, above a footwall shortcut, involving no reactivation of Early Cretaceous normal faults In contrast, we describe field evidence for compressional reactivation of Early Cretaceous normal faults. Our methods are both structural and stratigraphical. Using new stratigraphical correlations, we have remapped parts of sheet K-12 (Guateque) of the geological map of Colombia ( Ulloa et al., 1975), along a transect crossing the northern tip of the Quetame Massif and the Sub-Andean foothills, into the Llanos basin. For the $\mathrm{CO}$ and foothills, we interpreted part of a seismic section and were able to consult additional subsurface data. On this basis, we constructed a regional balanced cross-section, so constraining the geometry of Early Cretaceous half-grabens and the amount of Andean shortening. 


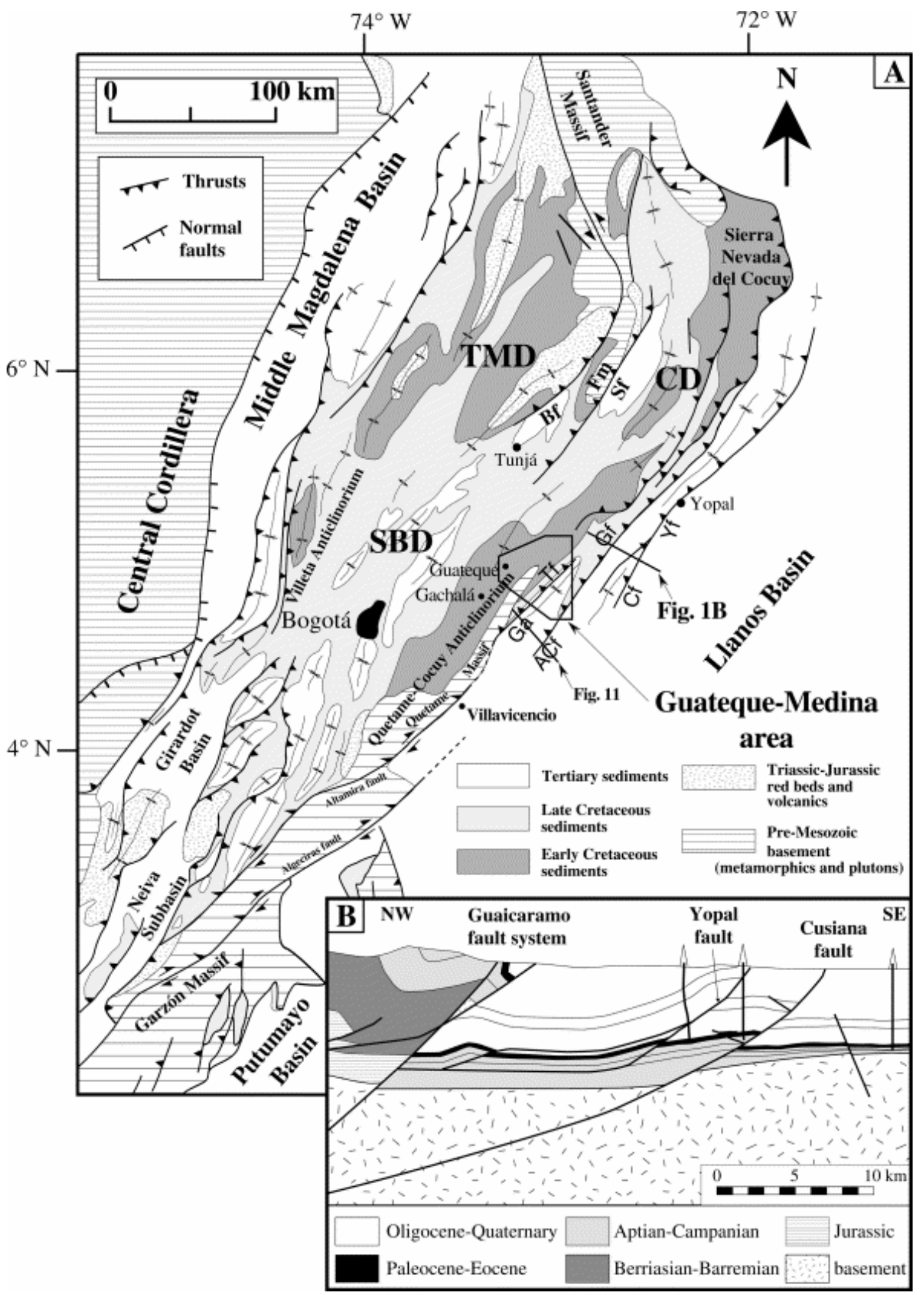

Fig. 1. (A) Structural map of the Cordillera Oriental (modified from Schamel and Gonz). Early Cretaceous depocenters (TMD: Tablazo-Magdalena; CD: Cocuy) merge southward into single Sabana de Bogotá depocenter (SBD). Ga: Guavio anticline; ACf: Agua Clara fault, Gf: Guaicáramo fault; Tf: Tesalia fault. (B) Cross-section through the Cusiana giant oil field (redrawn from Cooper et al. (1995)). The main structural feature is the out-of-sequence Guaicáramo thrust resulting from the Andean inversion of a major basin bounding normal fault. 


\section{Tectonic setting of the cordillera oriental}

The Colombian Andes consist of three sub-parallel mountain chains, the Occidental, Central and Oriental cordilleras (Fig. 2). Between them are deep intermontane basins, along which flow the main rivers of Colombia, the Cauca and Magdalena. South of $7^{\circ} \mathrm{N}$, the three cordilleras trend NNE; in Ecuador they merge into a single range. North of $7^{\circ} \mathrm{N}$, the CO bends into the major Santa Marta-Bucaramanga left-lateral fault which has as much as $110 \mathrm{~km}$ of slip (Campbell, 1968) and is the locus of present-day seismic activity ( Pennington and Taboada). Towards the foreland, the CO grades into the Sub-Andean foothills and the Llanos basin.

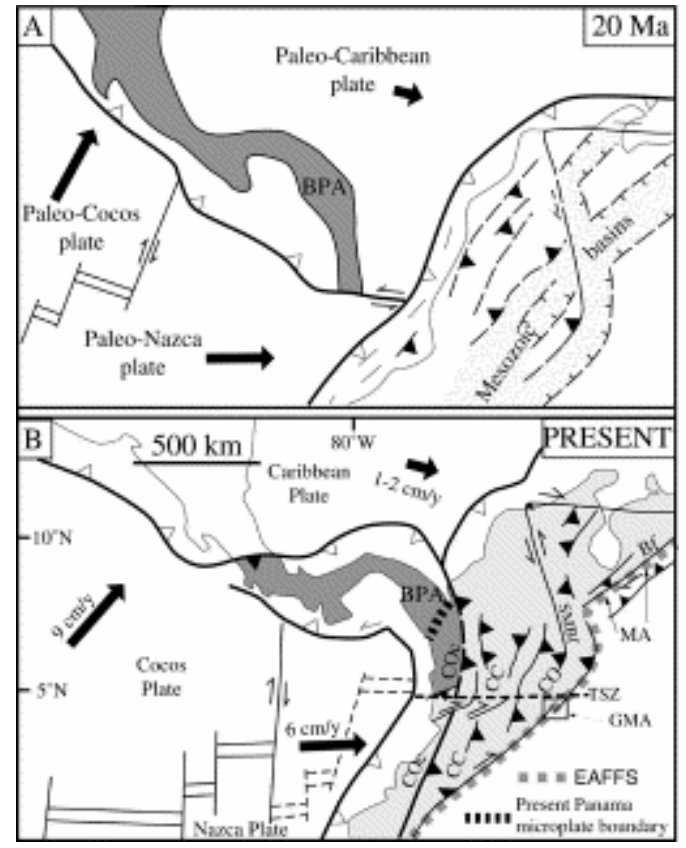

Fig. 2. Schematic tectonic reconstructions of northwestern South America and adjacent plates (A) at 20 Ma and (B) at present time (compiled and modified from Kellogg; Taboada and Trenkamp). COc: Cordillera Occidental; CC: Cordillera Central; CO: Cordillera Oriental; MA: Mérida Andes;.BPA: Baudo-Panama island arc (dark shaded area); SMBf: Santa Marta-Bucaramanga fault; GMA: Guateque-Medina area. See discussion section for explanation about: TSZ: Transform shear zone (i.e. southern limit of the Caribbean plate); Bf: Bocono fault; EAFFS: East Andean frontal fault system. Northwestern Andes are in light grey.

Since Triassic times, the three cordilleras have been through various episodes of subduction, accretion and collision, as north-western South America interacted with the oceanic Farallón/Nazca plate, the Caribbean plate and various island arcs (see review by Case et al. (1990)). However, the current structure and relief of the cordilleras result mainly from Neogene plate tectonics, which have overprinted earlier episodes. In early Neogene times (at about $25 \mathrm{Ma}$ ), the Farallón plate broke up, forming the Nazca and Cocos plates. As a result, the convergence direction between Nazca and South America changed abruptly, from SWNE to W-E (Pilger, 1983). Since $25 \mathrm{Ma}$, this convergence direction has remained steady (Fig. 2). For at least the last $45 \mathrm{Ma}$, the Palaeo-Caribbean plate has been subducting beneath the north-western corner of South America. Around $25 \mathrm{Ma}$, subduction became oblique. Its southeasterly motion has remained steady ever since (Freymueller and Kellogg). As a result of this subduction, the Baudo-Panama island arc collided with South America in middle Miocene 
times ( Duque-Caro, 1990) and the CO was uplifted during the ensuing Andean orogenic phase ( Colletta; Schamel; Cooper and Taboada).

Pre-Mesozoic basement of the CO crops out in the Santander, Floresta, Garzón and Quetame Massifs (Fig. 1), where it consists of Precambrian high-grade metamorphic rocks, early Paleozoic low-grade metamorphic rocks and late Paleozoic non-metamorphosed sediments. Its sedimentary cover, of Triassic to Tertiary age, is up to $10 \mathrm{~km}$ thick. Currently, the CO is a doubly verging fold-and-thrust belt (Fig. 1). Cretaceous sediments crop out on both flanks, forming the Villeta and Quetame-Cocuy anticlinoria. In contrast, the axial zone is a synclinorium, where Tertiary sediments are preserved. Thick-skinned and thin-skinned thrusts have been responsible for Andean inversion of a thick Mesozoic and Tertiary basin ( Campbell; Julivert; Colletta; Dengo; Cooper and Taboada), which formed in three stages.

1. In Triassic to Early Cretaceous times, continental rifting formed the Tablazo-Magdalena rift to the west and the Cocuy half-rift to the east (Fabre, 1987). Southward, the two rifts merged into a single and narrow basin, which now underlies the Sabana de Bogotá (EtayoSerna et al., 1969).

2. In Late Cretaceous times, post-rift thermal subsidence resulted in a single back-arc marine basin, which covered the entire area of the CO (Fabre, 1987).

3. In Maastrichtian to Paleogene times, the accretion of oceanic terranes, forming the presentday Cordillera Occidental, triggered deformation and uplift in the Cordillera Central. At the eastern edge of the Cordillera Central, the CO area became a large foreland basin (Colletta; Schamel and Cooper), in which several episodes of pre-Andean deformation have been recognized ( Cheilletz; Laumonier; Casero; Cheilletz; Restrepo; Branquet and Branquet).

During the Andean orogenic cycle, Mesozoic extensional faults became reactivated in compression. A notable example is the Boyacá fault, at the eastern edge of the TablazoMagdalena graben (Fig. 1). Another example is the bounding fault of the Cocuy half-graben, which was reactivated in compression as the SE-verging Guaicáramo fault and now forms the eastern front of the CO (Fig. 1).

\section{Morphology of the gma and surface data quality}

The GMA lies at the eastern front of the CO, between latitudes $4.7^{\circ} \mathrm{N}$ and $5.1^{\circ} \mathrm{N}$ (Fig. 1). Major structures in the area trend about $\mathrm{N} 30^{\circ} \mathrm{E}$ ( Fig. 3). We distinguish three domains, which are separated by the Tesalia and Agua Clara faults (Fig. 3).

First, to the NW of the Tesalia fault, the Quetame-Cocuy anticlinorium forms the eastern part of the CO. Altitudes range from $1200 \mathrm{~m}$ in the Chivor area to $3000 \mathrm{~m}$ in the Quetame Massif. Natural outcrops are rare, but good artificial exposures occur around the hydroelectric Chivor dam (or Represa La Esmeralda), which was built against Paleozoic basement of the Quetame Massif. The resulting lake (at about $1200 \mathrm{~m}$ ) has drowned the valley of the Garagoa (or Batá) river (Fig. 3). We were able to consult a report ( ISA (Interconexión Eléctrica SA), 1975), which was compiled by an engineering company, during the early phases of dam construction. At that time, foundations, tunnels, galleries, shafts and underground chambers were carefully logged, samples were analyzed and maps and sections were compiled at various scales (see Fig. 8A). Below the dam, the riverbed is now dry, so that exposures of Paleozoic basement are almost continuous. Above the dam, periodic fluctuations in water level have resulted in 
lakeside exposures of basement and its Early Cretaceous cover. Otherwise, in the Chivor district, numerous emerald deposits have been mined. They are hosted by Early Cretaceous strata. The largest deposits are above a Paleozoic basement block, in the hanging wall of the San Fernando reverse fault ( Fig. 3). Gypsum mines are also widespread in the GMA, notable examples being the old Lusitania mine, now flooded, and those at Páez (Fig. 3).

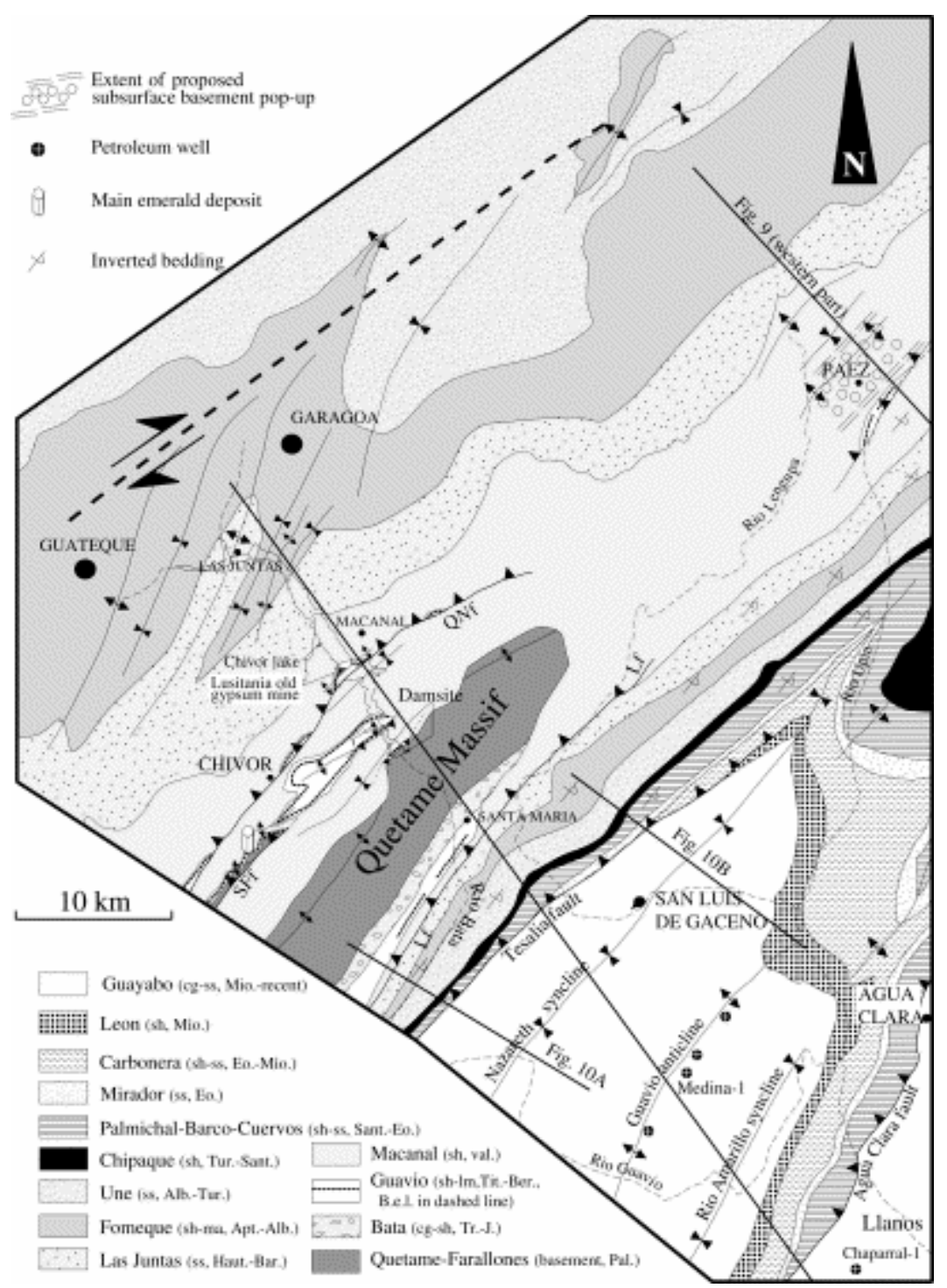

Fig. 3. Geological map of Guateque-Medina area (modified from Ulloa et al. (1975)). Section lines are for Las Juntas-Llanos cross-section ( Fig. 12) and western part of seismic profile TN-92-02 ( Fig. 9). For chronostratigraphy, see Fig. 4. B.e.l.: Brecciated evaporitic layer; cg: conglomerates; sh: shales; ss: sandstones; ma: marls; lm: limestones. Contours of Chivor lake and damsite are indicated.

Second, between the Tesalia and Agua Clara faults are the Guavio (or Medina) foothills (Fig. 3). Here, altitudes decrease sharply to between 600 and $1000 \mathrm{~m}$. Exposures are adequate along riverbanks and occasional roadside cuttings.

Third, to the SE of the Agua Clara fault, the featureless Llanos plains lie at an altitude of about $350 \mathrm{~m}$. 


\section{Stratigraphy of the GMA}

For our regional study, we reconciled two stratigraphic nomenclatures. One was introduced by geologists from INGEOMINAS, when mapping the Guateque sheet (Ulloa and Ulloa). The other has been used by petroleum geologists, when describing the Llanos basin ( Fig. 4). We also provide new data on Early Cretaceous sequences.

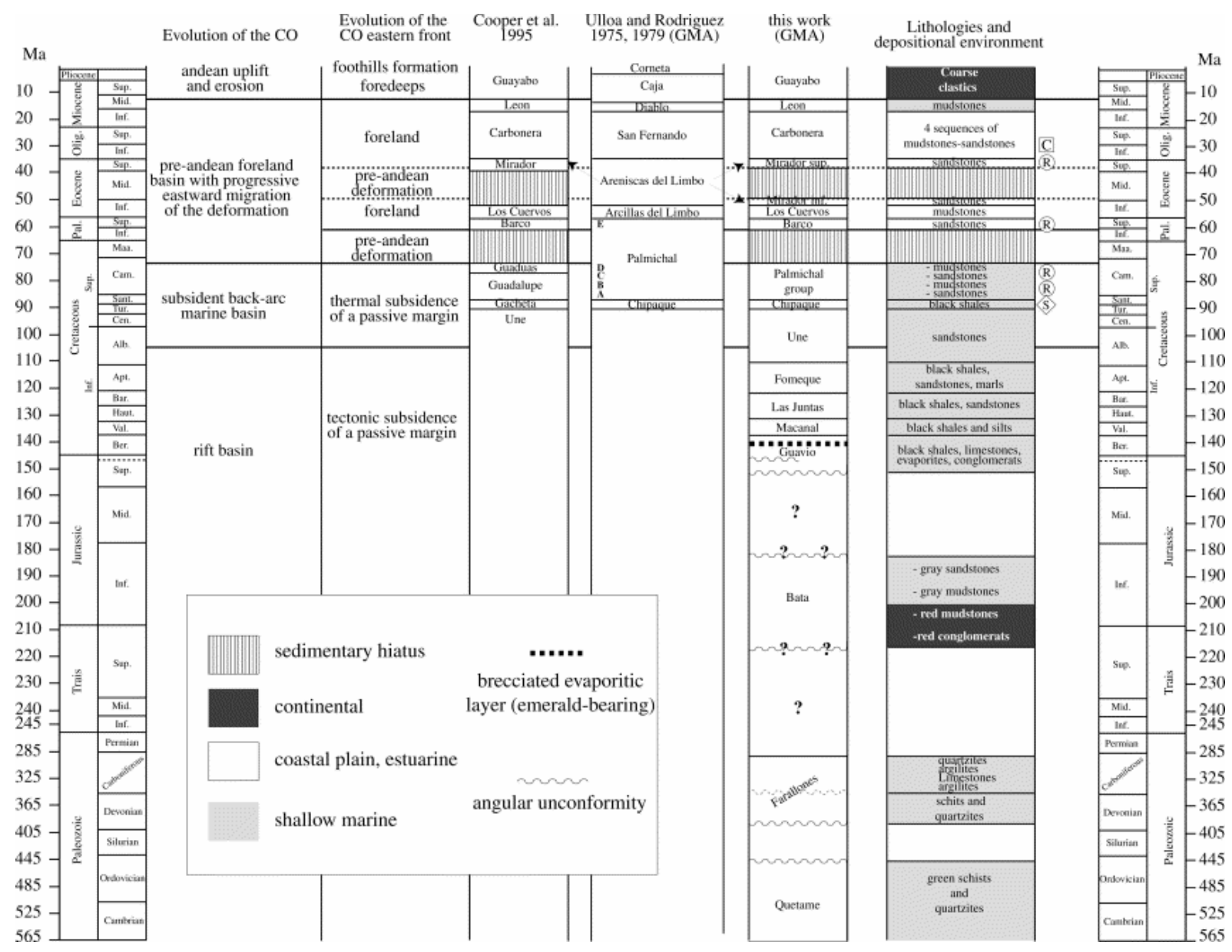

Fig. 4. Chronostratigraphy of Guateque-Medina area. Features of petroleum interest: R: reservoirs; C: cap rock; S: source rock. Compiled from Ulloa; Ulloa; Cooper; Cazier; Villamil; Vergara and Pulham.

\subsection{Basement}

The Quetame Massif (Fig. 3) is made of Paleozoic sedimentary rocks. The Quetame Formation, Cambro-Ordovician in age ( Campbell and Bürgl, 1965), underlies the Chivor dam and crops out along the dry bed of the Batá river. It consists of pelites and quartzites of lower greenschist grade. Lying upon it in angular unconformity are unmetamorphosed Devonian and Carboniferous sediments of the Farallones Formation (3600 m thick). Clearly, a major orogenic event occurred in late Ordovician or Silurian times (Galvis and Su) and was followed by uplift, erosion and subsidence. 


\subsection{Synrift sequences: Triassic to middle Albian}

At the eastern edge of the Quetame Massif (Fig. 3), the Batá Formation forms an isolated wedge of continental redbeds, Triassic to Jurassic in age (Bürgl, 1960). At its base is a slight angular unconformity. Throughout the CO, these redbeds accumulated in the hanging walls of normal faults during an early phase of rifting ( Colletta et al., 1990).

Early Cretaceous strata accumulated during a major marine transgression. The Guavio Formation (Tithonian to Berriasian) either rests conformably on the Batá Formation (e.g. around Santa María, Fig. 3) or oversteps it, to rest unconformably on Carboniferous basement (e.g. above the San Fernando fault in the Chivor area, Fig. 3). Marked lateral changes in thickness and facies are a feature of the Guavio Formation. The lower part consists of massive limestones and dolostones, which form cliffs and pinnacles up to $50 \mathrm{~m}$ high in the Gachalá area (Fig. 1), but are thin or absent in the GMA. The upper part of the Guavio Formation is late Berriasian in age ( Ulloa and Branquet). It hosts most of the emerald and gypsum deposits in the GMA ( Cheilletz; Branquet and Branquet). From bottom to top, it consists of (1) black shales and siltstones; (2) a brecciated evaporitic layer, 1-15 m thick, containing crushed black shales and gypsum lenses (Fig. 5A), which in places have been altered hydrothermally and may be emerald-bearing; (3) a massive whitish sequence, where micritic laminated limestones alternate with beds of anhydrite or gypsum; and (4) bioherms of micritic shelly limestones, which grade vertically and laterally into black shales, containing calcareous pebbly mudstones and olistostromes (Fig. 5B). Although the Guavio Formation tends to be heterogeneous and discontinuous, the brecciated evaporitic layer is of regional extent in the GMA ( Fig. 3).
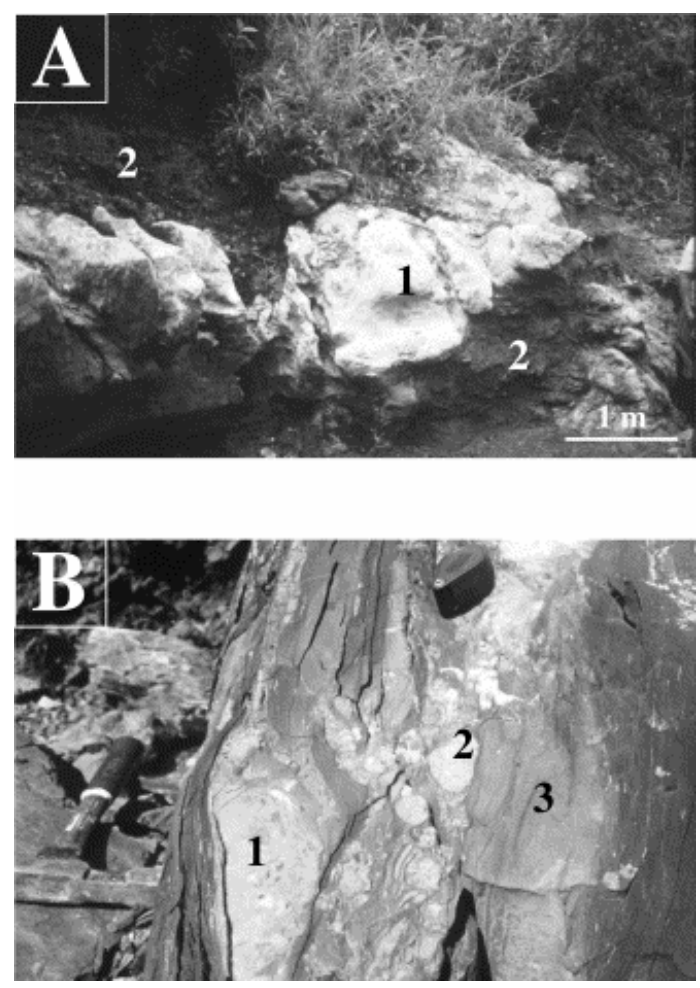

Fig. 5. Lithofacies of the Guavio Fm. (Tithonian to Berriasian), in the Guateque-Medina area. (A) Brecciated evaporitic layer composed of gypsum lenses (1), intercalated in crushed black shales (2). (B) Olistostrome (top of Guavio Fm) containing intraclasts of micritic limestone (1) and bioclastic limestone (2), embedded within a black mudstone matrix (3). Note that (1) includes second-order black mudstone intraclasts. Scale is given by handlens. 
Shallow-marine sandstones, black shales and marls of the Macanal, Las Juntas and Fómeque formations have resulted from Neocomian transgression. They show thickness variations across faults. In contrast, shallow-marine sandstones of the Une Formation are continuous and of more even thickness within the GMA. The inference is that rifting ended in the middle Albian (Villamil et al., 1998).

\subsection{Back-arc sequences: middle Albian to late Campanian}

During the Late Cretaceous, subsidence was more uniform and may have been largely thermal in origin (Fabre, 1987). In the Turonian, an eustatic rise in sea level led to deposition, under anoxic conditions, of the main hydrocarbon source rock, the Chipaque (or Gachetá) Formation (Cooper et al., 1995). A subsequent fall in sea level resulted in a shallow-marine siliciclastic shelf, on which were deposited shoreface sandstones of the Palmichal Group ( Fig. 4). Along the Guavio foothills, these rocks crop out almost continuously ( Fig. 3).

\subsection{Foreland sequences: late Campanian to middle Miocene}

Towards the end of the Cretaceous, the Cordillera Central underwent uplift and partial exhumation (Schamel and Dengo). The present-day CO was part of a large foreland basin and the GMA was at its eastern margin. There was a marked change, from shallow-marine conditions in the Late Cretaceous, to coastal and estuarine environments in the Paleocene ( Cooper et al., 1995). The Maastrichtian and early Paleocene are represented by a hiatus. A middle Eocene hiatus, which is widespread across the $\mathrm{CO}$, is manifest as a paraconformity within Mirador sandstones ( Pulham et al., 1997). Until the end of the middle Miocene, coastal-plain sandstones and shallow-marine mudstones of the Carbonera and León formations accumulated in the eastern part of the foreland basin (Cazier et al., 1995).

\subsection{Andean sequence: middle Miocene to Present}

As a result of uplift and erosion of the $\mathrm{CO}$ during the Andean orogeny, coarse continental clastics of the thick Guayabo Formation (Fig. 4) accumulated in foredeeps. Their western reaches have now been incorporated into the Guavio foothills ( Fig. 3).

\section{Las Juntas-Llanos transect}

\subsection{Outcrop data}

From Las Juntas to the Chivor dam, upright folds with hinges trending $\mathrm{N} 30^{\circ} \mathrm{E}$ are visible within Early Cretaceous strata (Fig. 3 and Fig. 6). Anticlines and synclines with angular hinges (kinks and box-folds) may have formed above detachments, in thin-skinned tectonic style (Suppe, 1983). In the Garagoa region, the axial traces of these upright folds are sigmoidal and we infer a right-lateral strike-slip fault zone, trending $\mathrm{N} 40^{\circ} \mathrm{E}$ ( Fig. 3). The Quebrada Negra anticline ( Fig. 6) lies within the hanging wall of a SE-verging thrust. At the Quebrada Negra gypsum mine (lakeside exposure of the flooded Lusitania gypsum mine), the anticline is cored by the brecciated evaporitic layer of the Guavio Formation (and not the Macanal Formation, as claimed by Ulloa et al. (1975)). Similar outcrops are scattered along the Quebrada Negra thrust. In the Quebrada Negra and Páez gypsum mines, secondary extensional shear bands, asymmetric boudins, drag folds and gypsum slickensides line the base of a thrust sheet and argue for Andean detachment within the brecciated evaporitic layer. 


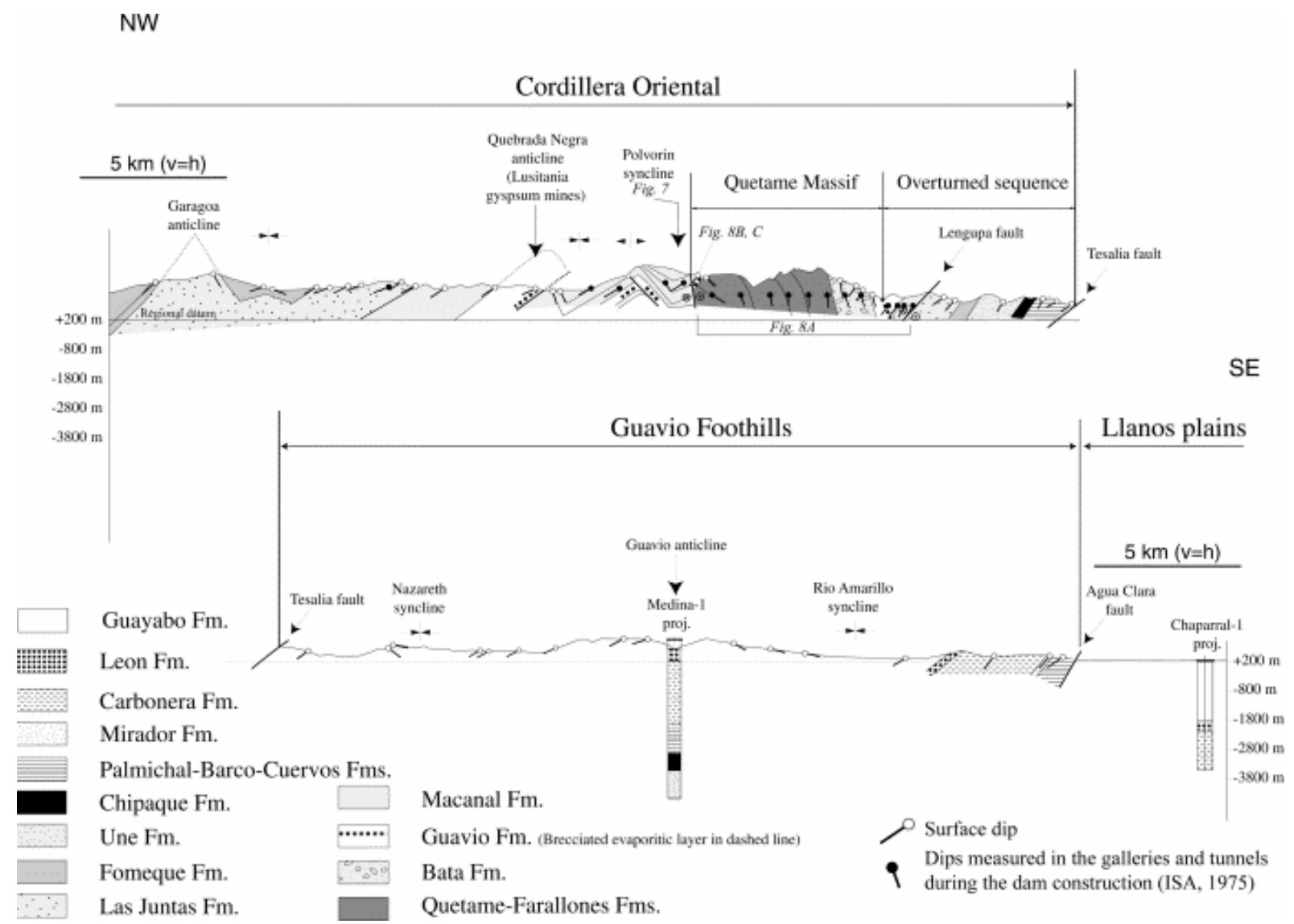

Fig. 6. Surface and well data for Las Juntas-Llanos cross-section. Data from the technical report of the Chivor dam construction (ISA (Interconexión Eléctrica SA), 1975) are included. For details, see Fig. 7 and Fig. 8. Structural domains described in text are Cordillera Oriental, Guavio foothills and Llanos plains.

In the Chivor area, the main structure is the San Fernando reverse fault, which involves basement and verges southeastwards (Fig. 3). In its hanging-wall, the Guavio Formation and the brecciated evaporitic layer form a series of left-stepping en-echelon folds, trending $\mathrm{N} 40^{\circ} \mathrm{E}$. Towards the lake, as the San Fernando fault becomes blind and attenuates, a NWverging thrust truncates the northernmost fold of this series ( Fig. 3). To the southeast, the Macanal shales crop out in the core of the Polvorín syncline (Fig. 7). Intercalated siltstones mark eastward stratigraphic thickening of the shale beds, which contain numerous slumps and debris-flow deposits. This is evidence for deposition in the hanging-walls of Early Cretaceous basin-bounding master faults.

The Quetame Massif is an uplifted basement block. Several authors have described it as bounded to the west by the Esmeralda extensional fault and to the east by the Santa María and Lengupa reverse faults (Ulloa; Ulloa and Rowan). However, according to our field observations and the technical report on the Chivor damsite ( ISA (Interconexión Eléctrica SA), 1975), the massif has been thrust westwards over the Polvorín syncline on a high-angle reverse fault (Fig. 6 and Fig. 8). This fault carries gently inclined striations and drag folds with steep axes, from which we infer a right-lateral component of slip. In its hanging wall is a triangular package of deformed and pyritized black shale, which is associated with the brecciated evaporitic layer of the Guavio Formation (Fig. 8B and C). Bedding in the shale lies parallel to a fault surface, which truncates green quartzites of the Quetame Formation, dipping $50^{\circ}$ eastward. The fault surface is striated down dip and strongly pyritized. Further to the east, the Farallones Formation (Devonian and Carboniferous) dips steeply eastward ( Fig. 8A). The 
Batá Formation (Jurassic) overlies it in paraconformity. In the Paleozoic rocks, to north and south of the dam, two anticlines trend $\mathrm{N} 35^{\circ} \mathrm{E}$ (Fig. 3).
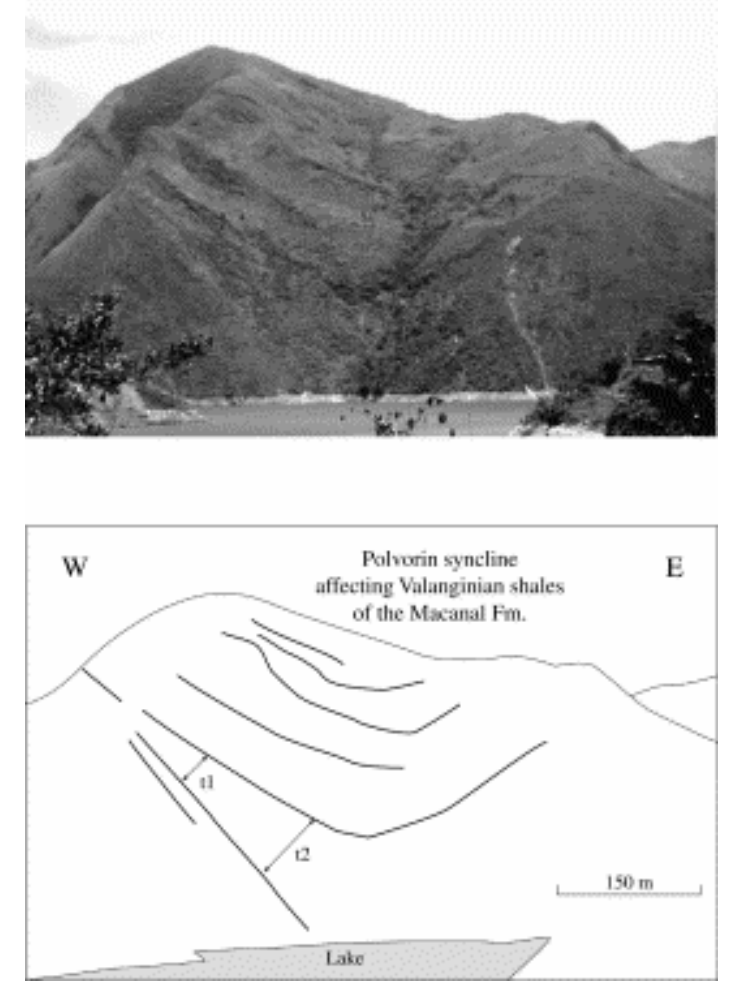

Fig. 7. Photograph and line drawing of Polvorín syncline, showing eastward thickening (t1-t2) of Macanal shales. For location, see Fig. 6.

From the eastern edge of the Quetame Massif to the SE-verging Tesalia thrust, the entire sedimentary sequence-Early Cretaceous to Eocene-is overturned (Fig. 3 and Fig. 6). Within it, the Lengupa fault carries gently inclined striations and right-lateral strike-slip duplexes. However, the Tesalia fault appears to be the main fault in this area: along our transect, NW-dipping Eocene Mirador sandstones in the hanging wall override recent Guayabo clastic sediment in the footwall. Thus, the throw of the Tesalia fault is at least the thickness of the Carbonera-Leon Formations, i.e. $2.5 \mathrm{~km}$. Within this overturned panel, the Early Cretaceous sequences are much thinner than around the Chivor lake. Although partly resulting from tectonic thinning of the overturned sequence, the large thickness variation is symptomatic of fault-controlled sedimentation during the Early Cretaceous. Near Santa María, the brecciated evaporitic layer of the Guavio Formation contains gypsum and may also contain halite at depth (there is a salt spring at Mámbita, southeast of Santa María). Olistostromes and slumped limestone beds with black shale intraclasts provide evidence for debris flows and dynamic resedimentation on steep slopes during Berriasian rifting and tilting. 

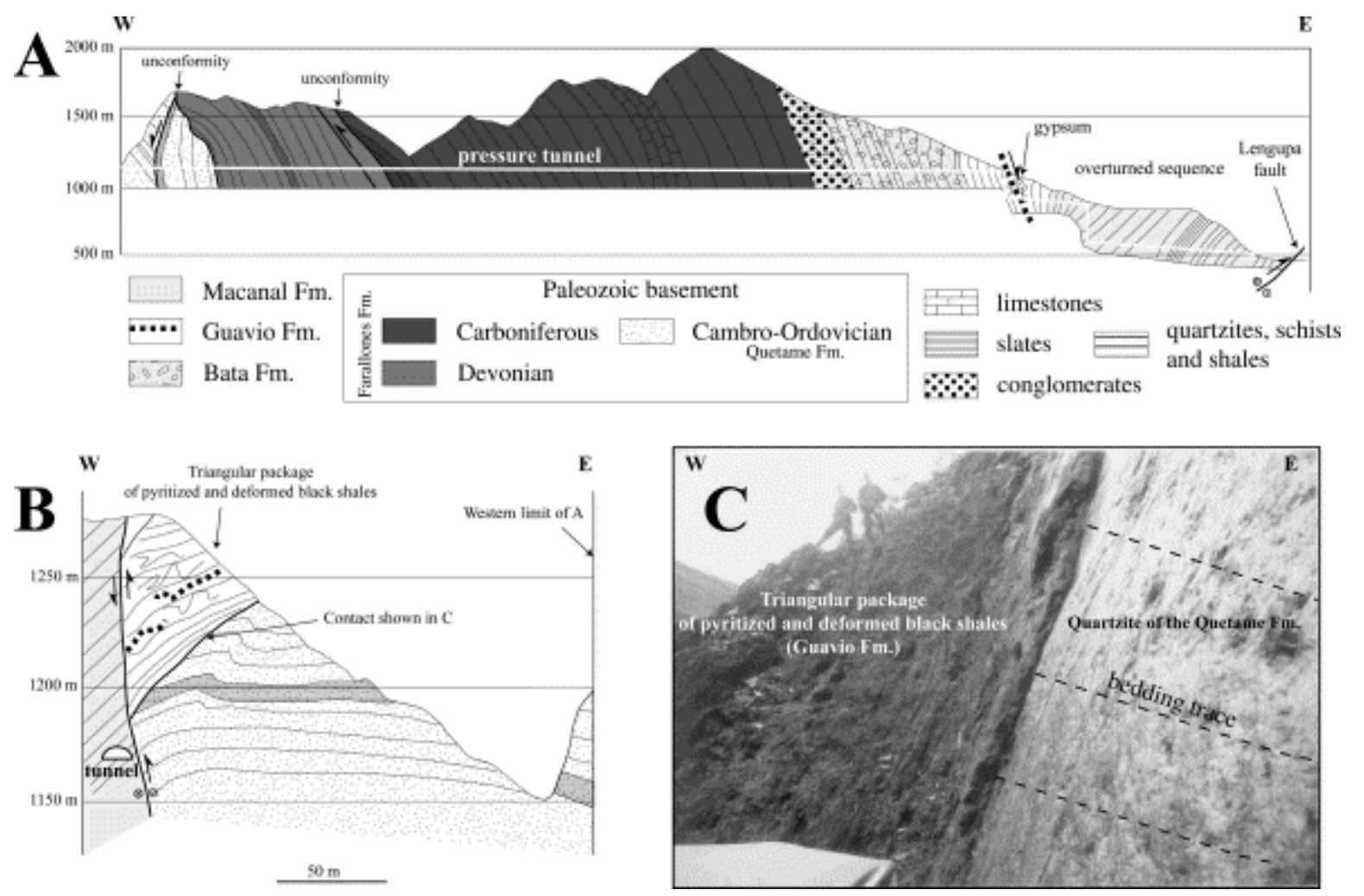

Fig. 8. (A) Cross-section of Quetame Massif along pressure tunnel of Chivor dam (modified from ISA (Interconexión Eléctrica SA) (1975)). Section is subparallel to regional cross-section Las Juntas-Llanos. Quetame Massif and Batá Fm. dip steeply eastwards. (B) Cross-section of western edge of Quetame Massif, thrust over eastern limb of Polovorín syncline. Triangular package of Guavio shales overlies Paleozoic sediments. (C) Photograph of contact between Paleozoic quartzites and Guavio shales. On (A) and (B), dashed line indicates brecciated evaporitic layer. For locations of (A), (B) and (C), see Fig. 6.

The symmetric Guavio anticline lies between the Nazareth and Rio Amarillo synclines (Fig. 6). At the eastern edge of the foothills, the Agua Clara fault, SE-verging, brings the Palmichal Group to the surface. East of the Agua Clara fault, coarse clastic sediment of the Guayabo Formation covers the Llanos basin.

\subsection{Subsurface data}

Seismic profile TN-92-02 (Fig. 9) has been used to study structures at the northern tip of the Quetame Massif. This profile is strategic, because it provides constraints on the geometry of the Quetame Massif as it plunges northward below its sedimentary cover (Fig. 3). However, the seismic quality of this profile is poor. The better western part has been interpreted with the help of surface data from our own fieldwork and from Ulloa et al. (1975). The more complex eastern part has been tentavily interpreted using surface data from ECOPETROL. The profile passes through the mines of Páez (Fig. 3), where gypsum, part of the brecciated evaporitic layer, occurs within an isolated package of the Guavio Formation, cropping out against a thrust. On the seismic profile, we interpret a series of strong reflectors as top basement ( Fig. 9B). To the northwest, this surface is offset by thrusts, SE-dipping and responsible for some folding. To the southeast, the opposite vergence is visible. Between the two sets of thrusts is a basement pop-up ( Fig. 3 and Fig. 9 in map view). Its bounding faults appear to converge downward. The doubly verging faults and central pop-up ( Fig. 9C) can be interpreted, either as a basement shortcut (the compressional offset of a tilted rift shoulder) with an associated 
back-thrust, or as a basement-involved positive flower structure, which formed in a transpressional setting ( Harding; Sylvester and Richard). These contrasting interpretations will be discussed later.
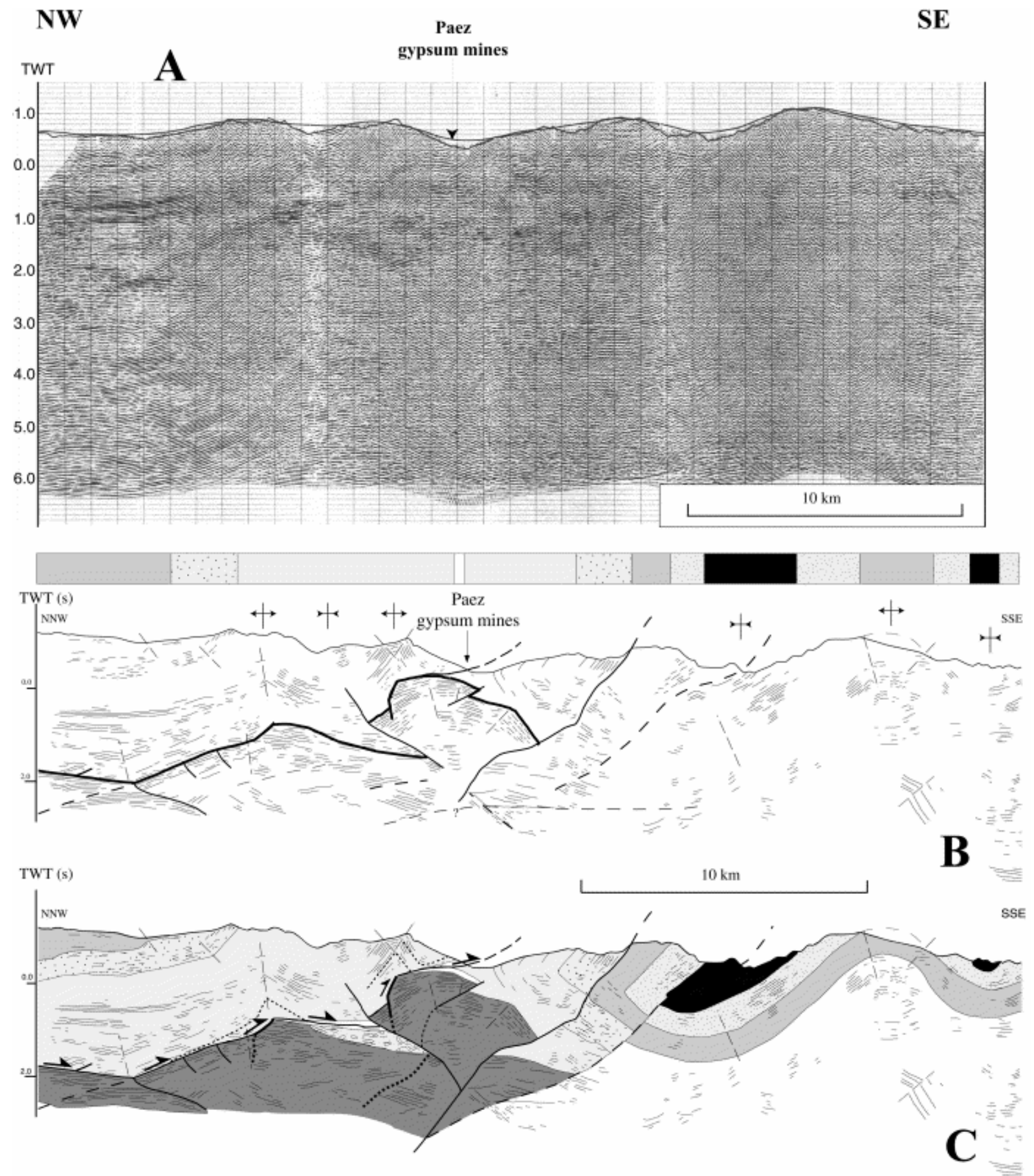

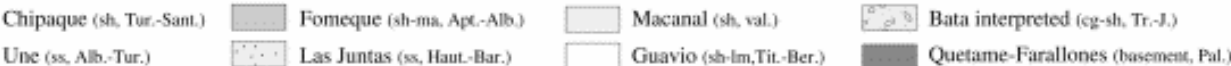

Fig. 9. Part of time-migrated seismic profile TN 92-02 (A, courtesy of ECOPETROL), line drawing (B) and interpretation (C). For location, see Fig. 3. Surface data are from our field works, Ulloa et al. (1975) and ECOPETROL (personal communication). On (B), thick black line is top of Paleozoic basement. On (C), detachments and ramps are indicated by black arrows. Ramps are inferred along Early Cretaceous normal faults. 
Across the basement pop-up, the large variation in thickness of the Macanal Formation (Early Cretaceous) is probably a result of fault-controlled sedimentation. Along the north-western part of the section, kink folds and box folds in Early Cretaceous strata (Fig. 9B) may have formed by fault-bend folding above detachments and ramps ( Fig. 9C). One detachment appears to be at the interface between basement and cover; another, within the brecciated evaporitic layer of the Guavio Formation, as at the Páez gypsum mines (Fig. 9C). The ramps may be Early Cretaceous normal faults, reactivated during Andean deformation. This might provide an explanation for the large thickness variations in the Macanal shales. We also tentatively identify an eastward-thickening wedge of early-rift redbeds of the Batá Formation (Triassic to Jurassic).

Three short sections, drawn from NW-SE seismic profiles, provide details of major structures in the Guavio foothills and also constrain the timing of deformation (Fig. 10 and Fig. 11). The Tesalia fault has several strands, which anastomose downward (Fig. 10A). A blind fault dips eastwards under the western limb of the Guavio anticline (Fig. 10B). This anticline attenuates strongly, as it plunges south-westward. The Agua Clara fault appears to have thin-skinned and thick-skinned components ( Fig. 11). A detachment and related ramp (marked by a clear hanging-wall flat) overlie steep faults, which probably involve basement and which presumably were active in the Tertiary. The hanging wall of the thrust has been exhumed, almost as far down as the top of the Chipaque Formation. Within the Guayabo coarse clastic sediment, the lack of growth (synkinematic) strata next to faults and the uniform thicknesses of folded layers indicate that most of the deformation in the foothills has accumulated since the end of the Miocene.

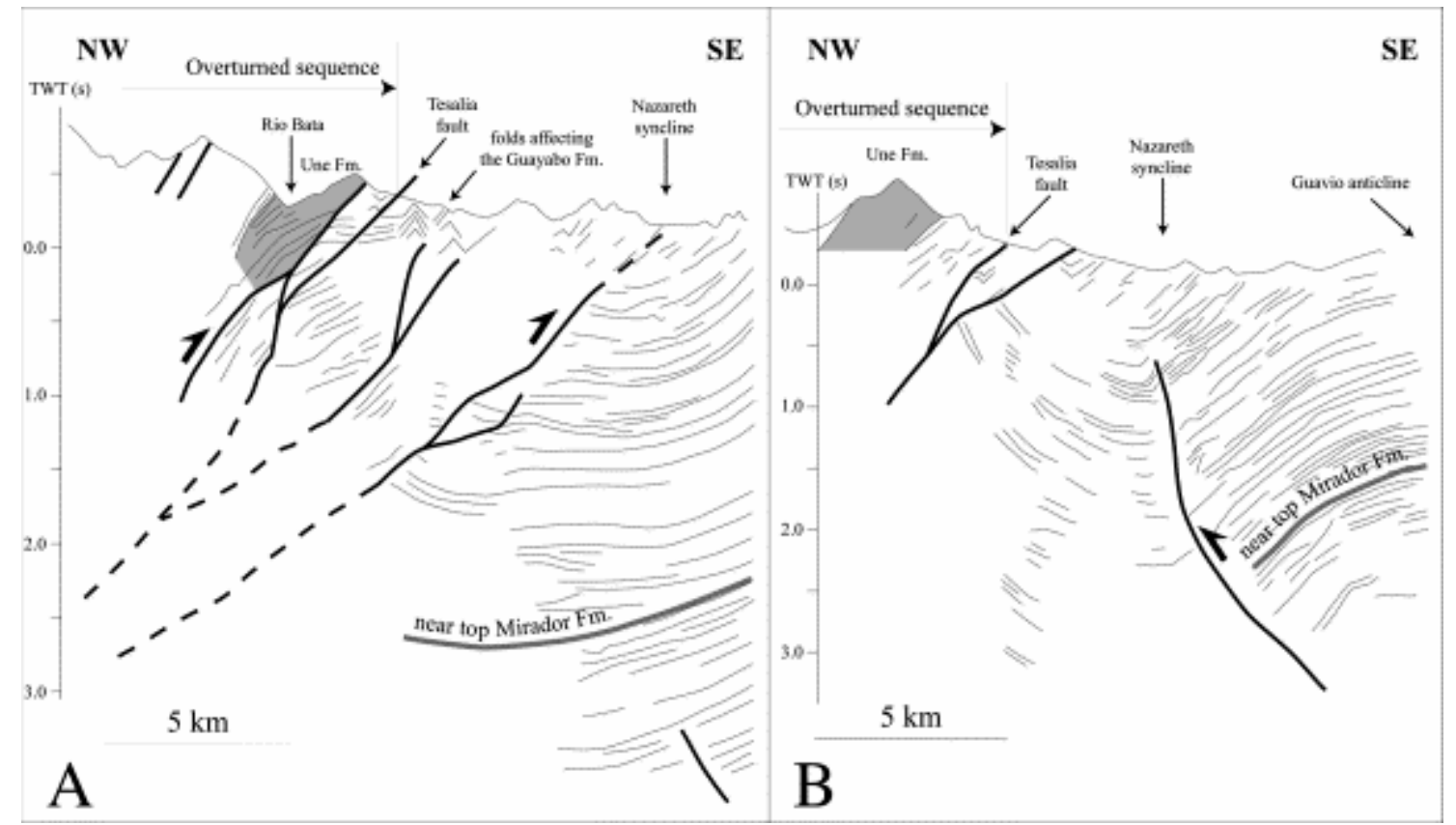

Fig. 10. Sketch sections across Tesalia fault and Nazareth syncline, to (A) south and (B) north of San Luis de Gaceno (for location, see Fig. 3). 


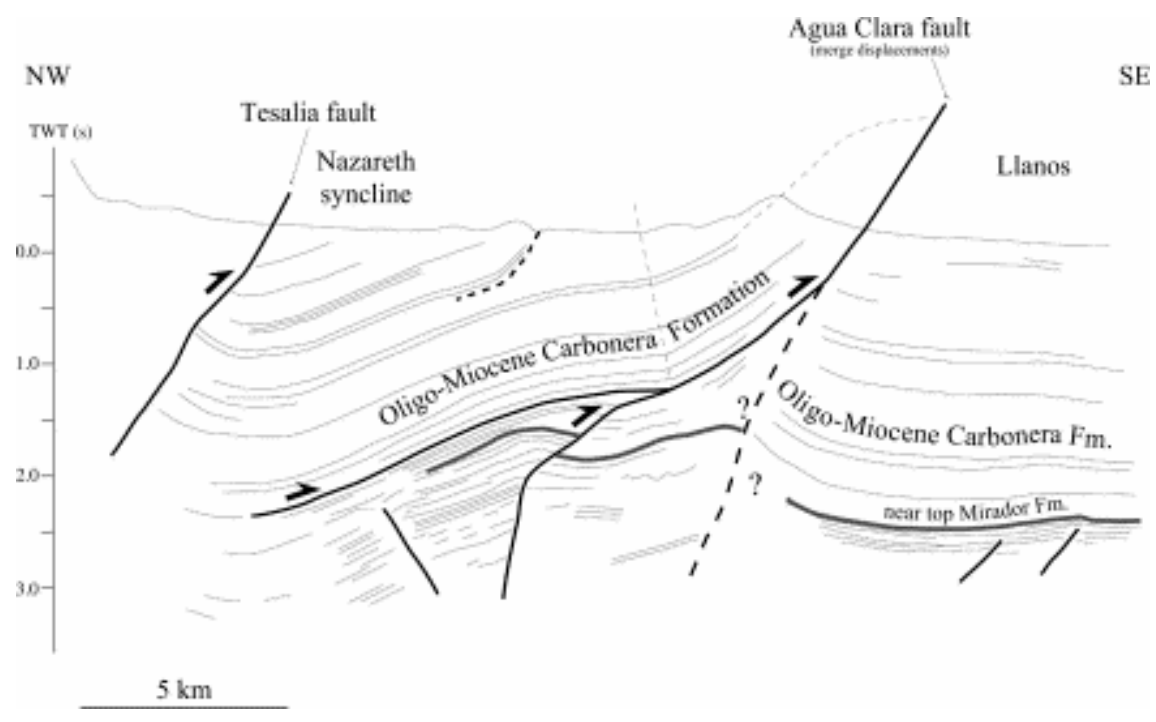

Fig. 11. Sketch section south of Guavio anticline (for location, see Fig. 1A).

\section{Balanced cross-section and structural interpretation}

On the basis of surface and subsurface data, we have drawn a regional section from Las Juntas to the Llanos (Fig. 12A). The section has been balanced and restored (Dahlstrom, 1969), assuming that (1) the top of the shallow-marine Une Formation (Cenomanian to Turonian) was horizontal at deposition, (2) Andean deformation was by pure thrusting in the plane of section ( Fig. 12B) and (3) areas (bed lengths and thicknesses) have been preserved. As kink folds and box folds are the most common in the GMA, we first identified the main dip panels and then used the kink method ( Suppe, 1985) to construct folds along the section. To account for these folds, we first applied geometric models of fault-bend and fault-propagation folding, as described by Suppe; Suppe; Suppe and Jamison. However, these models do not provide a unique solution. To allow for reactivation of faults involving basement, we followed Mitra (1993), adding the following assumptions and simplifications: (1) as shown by the folds on Fig. 3, we allowed basement to undergo some ductile deformation; (2) we did not take into account extensional folds (i.e. 'drape folds' or 'extensional fault-propagation folds'); (3) we allowed steep or overturned limbs to undergo minor amounts of tectonic thinning. Finally, small-scale folds have been ignored, particularly in the Guateque-Garagoa area ( Fig. 3). 

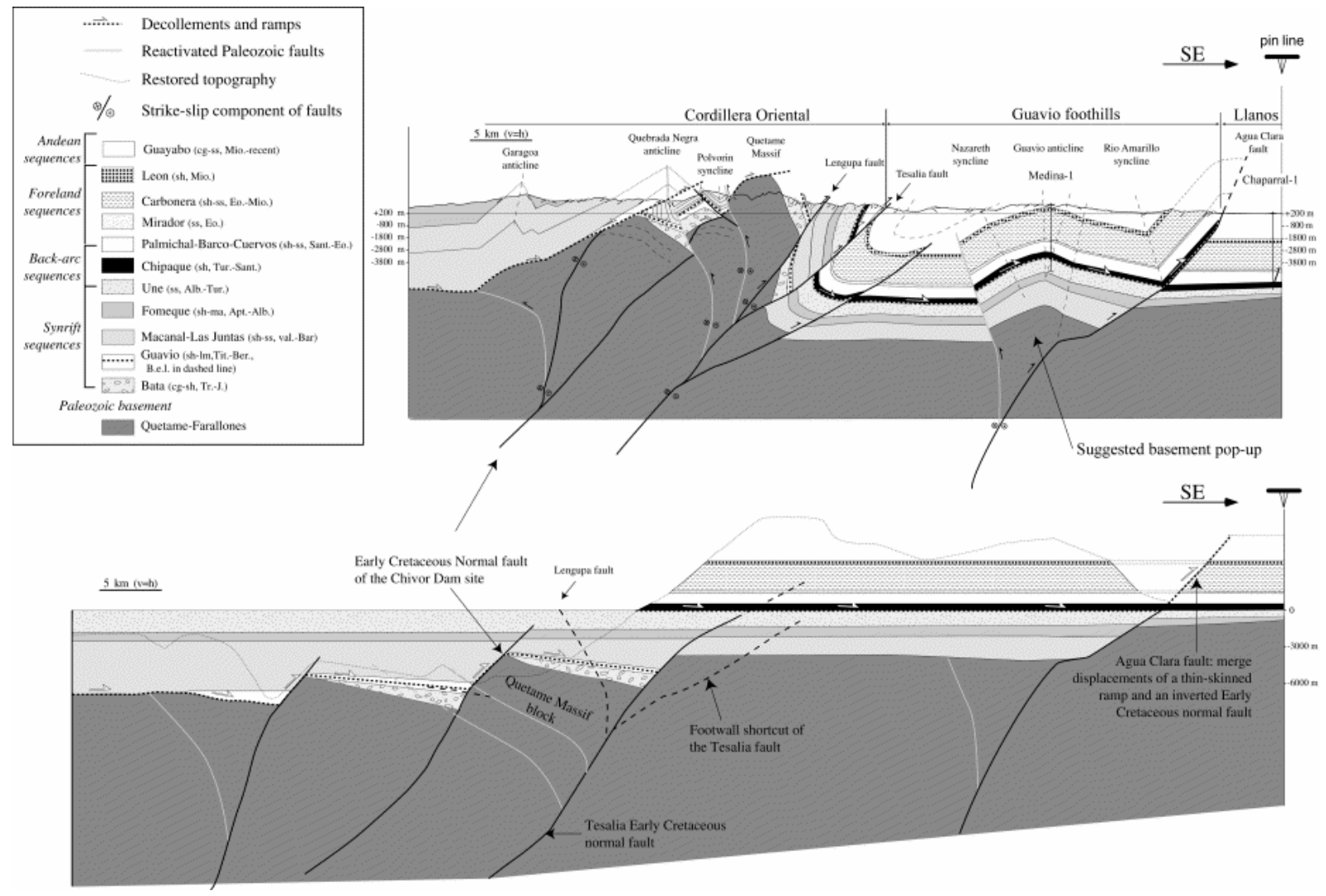

Fig. 12. Regional cross-section (Las Juntas-Llanos) in current state (top) and restored state (bottom). Restored state was obtained by flattening top of shallow-marine Une Formation (Cenomanian to Turonian) and assuming that deformation was in plane of section. See construction method and structural interpretation in text.

Rapid thickness variations, eastward stratigraphic thickening in the Macanal shales and olistotromes or slumps in the Guavio Formation, all provide evidence for synsedimentary activity on Early Cretaceous basin-bounding master faults, westward-dipping (see Ravnas and Steel, 1998). The Tesalia fault was one such fault. During Andean deformation, it became reactivated in compression ( Fig. 12), uplifting the eastern front of the CO. The Quetame Massif and adjacent overturned sequence resemble the model of 'fault-propagation folding with fault breakthrough', developed by Mitra (1993) to constrain inversion structures. Based on this model, we have interpreted the Quetame structure as follows ( Fig. 12).

1. The Quetame Massif and present-day overturned sequence were once in the hanging wall of the Tesalia normal fault.

2. Compressional reactivation of the Tesalia fault resulted in a broad fault-propagation fold (now partly eroded). Its steep forelimb is the western limb of the Nazareth syncline.

3. Further propagation of the Tesalia thrust fault through the forelimb caused south-eastward translation of the fault-propagation fold (see Mitra, 1990).

To the east of the Quetame Massif, we interpret the Lengupa fault as a secondary thrust in the hanging wall of the main Tesalia fault. Another (unnamed) fault is shown as a footwall shortcut of the main Tesalia fault. To the west, the Quetame Massif block is bounded by the Early Cretaceous normal fault of the Chivor damsite (Fig. 12). Further to the west, a similar structural style has been adopted for the small block underlying the Polvorín syncline. 
According to our interpretation, both basement blocks were uplifted, as a result of reverse motions on the reactivated Tesalia fault and on back-thrusts branching out of it. The backthrusts can be interpreted, either as Paleozoic faults, reactivated in Andean times, or as newly formed Andean back-thrusts (see discussion below). In any case, our interpretation contrasts with the sketch section of Rowan and Linares (2000, fig. 3), in which the Quetame Massif figures as the offset corner of a tilted rift shoulder, above a footwall shortcut, involving no reactivation of Early Cretaceous normal faults.

In the Guavio foothills, based on the tectonic style to the west, the back-thrusts (Fig. 10B) and the steep faults at depth ( Fig. 11), we interpret the core of the symmetric Guavio anticline as a basement pop-up ( Fig. 12): this appears to be a realistic alternative to the fault-bend fold interpretation ( Rowan and Linares, 2000). The Agua Clara fault is at the southern end of the Guaicáramo fault system (Fig. 1), which was described previously as a major reactivated basement fault ( Cooper et al., 1995). This is consistent with our interpretation in depth of the Agua Clara fault as a reactivated rift-bounding normal fault (responsible for a small displacement in this area) which, branches into a thin-skinned ramp upward ( Fig. 12).

In the GMA, we have identified three detachments, that are compatible with the mechanical stratigraphy (Fig. 12): (1) between Early Cretaceous cover (black shale) and basement (quartzites); (2) within the brecciated evaporitic layer of the Guavio Formation; (3) at the base of the Chipaque black shale (hydrocarbon source rock). In the western part of the crosssection, kink folds are assumed to have formed above the detachment between cover and basement. Detachment folding has formerly been recognized west of the Quetame Massif ( Linares, 1996). Sparse shear bands, drag folds, secondary extensional shear bands, asymmetric boudins and gypsum slickensides show that the brecciated evaporitic layer within the Guavio Formation became an Andean detachment. Early Cretaceous normal faults seem to have acted as ramps between these detachments, as suggested by geometric relationships and striations observed at the dam site ( Fig. 8) and by subsurface data ( Fig. 9). Finally, because the eastern limb of the Rio Amarillo syncline forms a hanging-wall flat against the Agua Clara fault, a detachment is required at the base of the Chipaque Formation.

Deformation is interpreted to be a forward breaking sequence in 5 stages.

1. Early detachments at the basement-cover interface and within the Guavio Formation formed as a result of shortening in westernmost areas.

\section{Detachment folds formed in the Garagoa area.}

3. In the Quebrada Negra area, fault-bend and fault-propagation folding occurred above ramps that are thought to be Early Cretaceous normal faults.

4. Basement-involved faults (e.g. the Tesalia fault) were reactivated. By folding and crosscutting earlier detachments, they triggered the uplift of the Quetame Massif and adjacent basement blocks. In the Guavio foothills, the detachment at the base of the Chipaque black shales might have been coeval, accommodating changes in length associated with folding and with protrusion of basement blocks into the cover (Narr and Suppe, 1994).

5. The Agua Clara normal fault and associated back-thrust were reactivated in compression, folding the Chipaque detachment within the Guavio anticline. Reverse slip along the Tesalia 
fault caused new uplift of the Quetame Massif with truncation of the Chipaque detachment. As the result, the Tesalia fault is out-of-sequence.

From our balanced section, the amount of shortening (Fig. 12) is 28\%. This is consistent with values of $25 \%$ ( Cooper et al., 1995) or 33\% ( Colletta et al., 1990), which were calculated from balanced cross-sections of the entire CO.

\section{Discussion}

\subsection{Style of Andean deformation in the GMA}

We have provided evidence for compressional reactivation of Early Cretaceous normal faults in the GMA, but we have not yet discussed under what conditions they formed. Are the basement pop-ups due to reverse faulting alone or are they positive flower structures, which formed by wrenching?

Evidence for wrenching is not abundant, but it is consistent.

1. Gently dipping striations, drag folds with steep axes and small-scale strike-slip duplexes occur along the faults bounding the Quetame Massif. They indicate right-lateral slip.

2. In the Garagoa area (Fig. 3), sigmoidal axial traces of folds are consistent with motion along a right-lateral wrench zone, above a detachment between cover and basement.

Thus we suggest that the northern end of the Quetame Massif is a right-lateral basementinvolved positive flower structure (Fig. 12), containing several pop-ups ( Fig. 9) and anticlines ( Fig. 3).

In brittle rock, which fails according to a Navier-Coulomb stress envelope, a normal fault will reactivate as a pure reverse fault under horizontal compression, only if its dip is smaller than $46^{\circ}$ (Sassi et al., 1993). High-angle normal faults reactivate more readily under oblique compression, which gives them both dip-slip (reverse) and strike-slip components ( Letouzey; Nalpas and Brun). Moreover, a strike-slip component might explain the reactivation of high-angle normal fault as thin-skinned ramps between lower and upper detachments ( Fig. 12): the neoformation of a ramp above the old normal fault is not required. If strike-slip displacements occurred in the GMA, our regional cross-section ( Fig. 12) may not be properly restored and the calculated shortening may be in error.

It may seem surprising that folds in the hanging wall of the San Fernando fault and anticlines in the Quetame Massif are left-stepping (Fig. 3), because such a pattern is incompatible with right-lateral transpression. We suspect that these folds and NW-verging back-thrusts are reactivated Paleozoic structures. Regionally, it has been shown that the eastern front of the CO was a suture in early Paleozoic times ( Galvis; Su and Casero).

\subsection{Structural style of the Llanos foothills}

The structural style we described in the GMA is similar to that described for the CusianaYopal area (Fig. 1B; Cooper et al., 1995). In both areas, reactivated Early Cretaceous normal faults (Tesalia, Guaicáramo-Agua Clara and Cusiana faults) are associated with thin-skinned 
thrusts. Along strike, these reactivated normal faults appear to be right-stepping (Fig. 1A). This might be controlled by en-echelon rift fault pattern along eastern margin of the Cocuy half graben. However, the uplift related to basement-involved structures is more important in the GMA than northeastward. This difference may result from right-lateral slip along the Altamira fault system ( Fig. 1A). The age of wrenching along this fault system is not constrained, but a large part of the movement could have been absorbed by basementinvolved faults in the GMA.

Finally, it is noteworthy that branch lines of basement-involved faults are commonly buried by thin-skinned ramps (e.g. Chipaque detachment on Fig. 12, and Yopal fault on Fig. 1A). This makes it difficult to interpret subsurface data.

\subsection{Compatibility with regional deformation and plate tectonics}

According to focal mechanisms of earthquakes and GPS studies (Pennington; Kellog; Freymueller and Kellogg), the mountain ranges of Ecuador, Colombia and Venezuela and their intermontane basins, all form a semi-coherent sub-plate, the North Andean block. Relative to the Guiana craton, the North Andean block is currently moving north-eastwards at about $10 \mathrm{~mm} /$ year. The active boundary is the East Andean frontal fault system, which includes the Pallantaga and Illiniza faults in Ecuador, the eastern front of the CO in Colombia and the Boconó fault in Venezuela (Fig. 2).

In detail, the North Andean block is deforming internally. Indeed, it seems to have done so for most of Neogene time. On the basis of structural studies and seismic interpretation, the CO has been divided into two structural domains: a northern one, where SE-verging thrusts are dominant (for example, the Boyacá and Soapaga faults, Fig. 1) and a southern one, where strike-slip faults are common ( De Freitas et al., 1997). Similar conclusions have been drawn from plan-view restoration of Neogene fault blocks ( Sarmiento-Rojas and Nieuwland, 1999).

According to focal mechanisms of earthquakes and fault-slip data, current motions differ, from one domain to the other (Taboada et al., 2000). To the north of latitude $5^{\circ} \mathrm{N}$, pure thrusting dominates. It can be attributed to ESE-directed subduction of the paleo-Caribbean plate beneath South America and on-going collision with the Baudo-Panama arc. This tends to validate the assumption of in-plane motions for those cross-sections of the CO ( Colletta; Dengo and Cooper), which have been drawn and restored in a NW-SE direction. At latitude $5^{\circ} \mathrm{N}$, Taboada et al. (2000) have identified a major E-W-trending right-lateral shear-zone (TSZ, Fig. 2), which they believe lies above the southern edge of the subducted paleoCaribbean plate. Finally, south of latitude $5^{\circ} \mathrm{N}$, transpression is dominant and can be attributed to eastwards oblique subduction of the Nazca plate beneath South America.

As the GMA is at about $5^{\circ} \mathrm{N}$ (Fig. 2), both right-lateral motions and crustal thickening can be expected there. Thus our interpretation of the Quetame Massif as a positive flower structure is compatible with what is known about the regional deformation and plate tectonics in the northern Andes. 


\section{Conclusions}

1. In the Guateque-Medina area, Early Cretaceous strata show marked changes in thickness across large extensional faults.

2. A brecciated evaporitic layer, that is locally emerald-bearing, forms part of the Guavio Formation (Tithonian to Berriasian), near the base of the synrift sequence. This layer is of regional extent in the Guateque-Medina area and probably also within neighbouring areas along the eastern front of the Cordillera Oriental.

3. In the foothills of the Guateque-Medina area, the entire sedimentary sequence, from the Early Cretaceous to the late Miocene, shows folding and thrusting of Andean age.

4. During Andean deformation, the brecciated evaporitic layer acted as an upper detachment. The interface between basement and cover provided a lower detachment. Early Cretaceous normal faults were reused as ramps between both detachments.

5. Also as a result of Andean deformation, extensional faults of Early Cretaceous age were reactivated as reverse faults. The most notable example is the SE-verging Tesalia fault, which was the edge of the Cocuy half-rift in the Early Cretaceous.

6. The Paleozoic Quetame Massif was uplifted in the hanging wall of the Tesalia fault. The massif now forms a pop-up, between the Tesalia fault and a series of back-thrusts.

7. According to fold patterns and fault-slip data, reverse faulting was accompanied by rightlateral wrenching. The basement pop-up of the Quetame Massif may therefore be a positive flower structure, which formed in right-lateral transpression.

8. From in-plane restoration of a regional cross section, Andean shortening across the area is $28 \%$. However, this value may be in error, because of unknown amounts of out-of-plane displacement, due to right-lateral wrenching.

9. The style and timing of Andean deformation in the Guateque-Medina area are compatible with what is known about regional deformation and plate tectonics in the northern Andes. Right-lateral wrenching was probably due to eastwards oblique subduction of the Nazca plate beneath South America.

\section{Acknowledgements}

Funds for this study came from the French Ministry of Education and the European Commission (Directorate General XII, grant CT 94-0098). Minerales de Colombia S.A. (MINERALCO) provided invaluable logistic support. We are especially grateful to Plutarco Teatín-Margfoy and Carlos A. Alfonso P., both of Empresa Colombiana de Petróleos (ECOPETROL), for releasing part of seismic line TN-92-02. We thank Ingeniero Rafael Cotes Medina of Interconexión Eléctrica S.A. (ISA), for providing help, hospitality and access to an unpublished report on the geology of the Chivor damsite. We also thank Alfredo Taboada for helpful discussion. Reviewers' comments greatly improved the manuscript. 


\section{References}

Branquet, 1999. Branquet, Y., 1999. Etude structurale et métallogénique des gisements d'émeraude de Colombie: contribution à l'histoire tectono-sédimentaire de la Cordillère Orientale de Colombie. PhD Thesis. Institut National Polytechnique de Lorraine, VandœuvreLès-Nancy, France, 295 p.

Branquet et al., 1999a. Y. Branquet, A. Cheilletz, G. Giuliani, B. Laumonier and O. Blanco , Fluidized hydrothermal breccia in dilatant faults during thrusting: the Colombian emerald deposits. Geological Society Special Publications, London 155 (1999), pp. 183-195.

Branquet et al., 1999b. Y. Branquet, B. Laumonier, A. Cheilletz and G. Giuliani , Emeralds in the Eastern Cordillera of Colombia: two tectonic settings for one mineralization. Geology 27 (1999), pp. 597-600.

Bürgl, 1960. H. Bürgl , El Jurásico e Infracretáceo del Rio Batá, Boyacá. Servicio Geológico Nacional de Colombia, Boletín de Geología 6 (1960), pp. 169-211.

Brun and Nalpas, 1996. J.P. Brun and T. Nalpas , Graben inversion in nature and in experiments. Tectonics 15 (1996), pp. 677-687.

Campbell, 1968. C.J. Campbell , The Santa Marta wrenck fault of Colombia and its regional setting. Transactions of Caribbean Geological Conference, 4th (1968), pp. 247-261.

Campbell and Bürgl, 1965. C.J. Campbell and H. Bürgl , Section through the Eastern Cordillera of Colombia, South America. Geological Society of America Bulletin 76 (1965), pp. 567-589.

Case et al., 1990. J.E. Case, R. Shagam and R.F. Giegengack, Geology of the northern Andes: an overview. Geological Society of America, The Geology of North America (1990), pp. 177-200.

Casero et al., 1997. P. Casero, J.-F. Salel and A. Rossato , Multidisciplinary correlative evidences for polyphase geological evolution of the foot-hills of the Cordillera Oriental (Colombia). Proceedings, VI Simposio Bolivariano, Exploración petrolera en las cuencas subandinas, Cartagena, Colombia, September 1997 vol. 1, Asociación Colombiana de Geólogos y Geofísicos del Petróleo (1997) pp. 100-118 .

Cazier et al., 1995. E.C. Cazier, A.B. Hayward, G. Espinosa, J. Velandia, J. Mugniot and W.G. Leel , Petroleum geology of the Cusiana field, Llanos basin foothills, Colombia. American Association of Petroleum Geologists Bulletin 7910 (1995), pp. 1444-1463.

Cheilletz and Giuliani, 1996. A. Cheilletz and G. Giuliani , The genesis of Colombian emeralds: a restatement. Mineralium Deposita 31 (1996), pp. 359-364.

Cheilletz et al., 1997. A. Cheilletz, G. Giuliani, Y. Branquet, B. Laumonier, A.J. Sanchez, G. Féraud and $\mathrm{T}$. Arhan , Datation $\mathrm{K}-\mathrm{Ar}$ et ${ }^{40} \mathrm{Ar} /{ }^{39} \mathrm{Ar}$ à $65 \pm 3 \mathrm{Ma}$ des gisements d'émeraude du district de Chivor-Macanal: argument en faveur d'une déformation précoce dans la Cordillère Orientale de Colombie. Comptes Rendus de l'Académie des Sciences Paris II 324 (1997), pp. 369-377. 
Colletta et al., 1990. B. Colletta, F. Hebrard, J. Letouzey, P. Werner and J.-L. Rudkiewicz , Tectonic and crustal structure of the Eastern Cordillera (Colombia) from a balanced crosssection. In: J. Letouzey, Editor, Petroleum and tectonics in mobile belts, Editions Technip, Paris, France (1990), pp. 80-100.

Cooper et al., 1995. M.A. Cooper, F.T. Addison, R. Alvarez, M. Coral, R.H. Graham, A.B. Hayward, S. Howe, J. Martinez, J. Naar, R. Penas, A.J. Pulham and A. Taborda , Basin development and tectonic history of the Llanos basin, Eastern Cordillera, and Middle Magdalena valley, Colombia. American Association of Petroleum Geologists Bulletin 7910 (1995), pp. 1421-1443.

Dahlstrom, 1969. C.O. Dahlstrom , Balanced cross-sections. Canadian Journal of Earth Sciences 6 (1969), pp. 743-757.

De Freitas et al., 1997. M.G. De Freitas, J.B.L. Françolin and P.R. Cobbold Proceedings, VI Simposio Bolivariano, Exploración petrolera en las cuencas subandinas, Cartagena, Colombia, September 1997Proceedings, VI Simposio Bolivariano, Exploración petrolera en las cuencas subandinas, Cartagena, Colombia, September 1997 vol. 2, Asociación Colombiana de Geólogos y Geofísicos del Petróleo (1997) pp. 38-41 .

Dengo and Covey, 1993. C.A. Dengo and M.C. Covey , Structure of Eastern Cordillera of Colombia: implications for trap styles and regional tectonics. American Association of Petroleum Geologists Bulletin 77 (1993), pp. 1315-1337.

Duque-Caro, 1990. H. Duque-Caro , The Chocó Block in the northwestern corner of South America: structural, tectonostratigraphic, and paleogeographic implications. Journal of South American Earth Sciences 3 (1990), pp. 71-84.

Etayo-Serna et al., 1969. F. Etayo-Serna, G. Renzoni and D. Barrero Primer Congresso Colombiano de GeologíaPrimer Congresso Colombiano de Geología, INGEOMINAS, Bogotá (1969).

Fabre, 1987. A. Fabre, Tectonique et génération d'hydrocarbures: un modèle de l'évolution de la Cordillère Orientale et du bassin des Llanos pendant le Crétacé et le Tertiaire. Archives des Sciences Genève 40 (1987), pp. 145-190.

Freymueller et al., 1993. J.T. Freymueller, J.N. Kellog and V. Vega , Plate motions in the North Andean Region. Journal of Geophysical Research 98 (1993), pp. 21853-21863. Abstract-INSPEC

Galvis and De La Espriella, 1987. J. Galvis and R. De La Espriella , La gran falla del Borde Llanero. Geología Colombiana 16 (1987), pp. 105-110.

González et al., 1988. González, H., Núñez, A., Paris, G., 1988. Mapa geológico de Colombia, scale 1:1 500 000. Ingeominas, 2 sheets.

Harding, 1985. T.P. Harding, Seismic characteristics and identification of negative flower structures, positive flower structures, and positive structural inversion. American Association of Petroleum Geologists Bulletin 69 (1985), pp. 582-600. 
ISA (Interconexión Eléctrica SA), 1975. ISA (Interconexión Eléctrica SA)Geología GeneralGeología General vol. II, Empresa de Energia Eléctrica de Bogotá and INGETEC, Bogotá, Colombia (1975) 60 maps .

Jamison, 1987. W.R. Jamison, Geometric analysis of fold development in overthrust terranes. Journal of Structural Geology 92 (1987), pp. 207-219.

Julivert, 1970. M. Julivert , Cover and basement tectonics in the Cordillera Oriental of Colombia and a comparison with other folded chains. Geological Society of America Bulletin 81 (1970), pp. 3623-3646.

Kellog et al., 1985. J.N. Kellog, I.J. Ogujiofor and D.R. Kansakar , Cenozoic tectonics of the Panama and North Andes blocks. Memoirs, VI Latin American Geological Congress, Bogotá, Colombia 1 (1985), pp. 40-59.

Kellogg and Vega, 1995. J.N. Kellogg and V. Vega , Tectonic development of Panama, Costa Rica, and the Colombian Andes: Constarints from Global Positioning System geodetic studies and gravity. Geological Society of America Special Paper 295 (1995), pp. 75-90.

Laumonier et al., 1996. B. Laumonier, Y. Branquet, B. Lopès, A. Cheilletz, G. Giuliani and F. Rueda , Mise en évidence d'une tectonique compressive Eocène-Oligocène dans l'Ouest de la Cordillère Orientale de Colombie, d'après la structure en duplex des gisements d'émeraude de Muzo et de Coscuez. Comptes Rendus de l'Académie des Sciences de Paris IIa 323 (1996), pp. 705-712.

Letouzey, 1990. J. Letouzey, Fault reactivation, inversion and fold-and-thrust belts. In: J. Letouzey, Editor, Petroleum and Tectonics in Mobile Belts, Editions Technip, Paris, France (1990), pp. 101-128.

Linares, 1996. Linares, R., 1996. Structural styles and kinematics of the Medina area, Eastern Cordillera, Colombia. MS Thesis. University of Colorado, Boulder, Colorado, 140 p.

Mitra, 1990. S. Mitra , Fault-propagation folds: geometry, kinematic evolution, and hydrocarbon traps. American Association of Petroleum Geologists Bulletin 746 (1990), pp. 921-945.

Mitra, 1993. S. Mitra , Geometry and kinematic evolution of inversion structures. American Association of Petroleum Geologists Bulletin 777 (1993), pp. 1159-1191. AbstractCompendex | Abstract-GEOBASE

Narr and Suppe, 1994. W. Narr and J. Suppe, Kinematics of basement-involved compressive structures. American Journal of Science 294 (1994), pp. 802-860.

Nalpas, 1994. Nalpas, T., 1994. Inversion des grabens du Sud de la mer du Nord. Published $\mathrm{PhD}$ thesis in the Mémoires de Géosciences-Rennes ( $\left.\mathrm{N}^{\circ} 71,1996\right)$. Rennes University, France, $245 \mathrm{p}$.

Pennington, 1981. W.D. Pennington, Subduction of the eastern Panama basin of northwestern South America. Journal of Geophysical Research 10 (1981), pp. 10753-10770. 
Pennington et al., 1979. Pennington, W.D., Mooney, W.D., Van Hissenhoven, R., Meyer, Hj., Ramirez, J., Meyer, R.P., 1979. Results of a microearthquake reconnaissance survey in Bucaramanga, Columbia. Geophysical Research Letters 6, 65-68.

Pilger, 1983. R. Pilger , Kinematics of the South American subduction zone from global plate reconstructions, in Geodynamics of Eastern Pacific Region. American Geophysical Union Geodynamics Series 9 (1983), pp. 113-126.

Pulham et al., 1997. A.J. Pulham, A. Mitchell, D. MacDonald and C. Daly , Reservoir modeling in the Cusiana field, Llanos foothills, Eastern Cordillera; Characterization of a deeply-buried, low porosity reservoir. Proceedings, VI Simposio Bolivariano, Exploración Petrolera en las cuencas subandinas, Cartagena, Colombia, September 1997 vol. 1, Asociación Colombiana de Geólogos y Geofísicos del Petróleo (1997) pp. 198-216 .

Ravnas and Steel, 1998. R. Ravnas and R.J. Steel , Architecture of marine rift-basin successions. American Association of Petroleum Geologists Bulletin 82 (1998), pp. 110-146.

Restrepo-Pace et al., 1998. P.A. Restrepo-Pace, F. Colmenares, C. Higuera and M. Mayorga , Fold and thrust belt along the western flank of the Eastern Cordillera of Colombia: style, kinematics and timing constraints derived from seismic data and detailed surface mapping. AAPG International Conference and Exhibition, Rio de Janeiro, Brazil, November 1998, Abstracts (1998) pp. 92-93 .

Richard, 1990. Richard, P., 1990. Champs de failles au dessus d'un décrochement de socle. Published $\mathrm{PhD}$ thesis in the Mémoires de Géosciences-Rennes ( $\left.{ }^{\circ} 85,1998\right)$. Rennes University, France, 382 p.

Roeder and Chamberlain, 1995. D. Roeder and R.L. Chamberlain , Eastern cordillera of Colombia: Jurassic-Neogene crustal evolution. American Association of Petroleum Geologists Memoir 62 (1995), pp. 633-645.

Rowan and Linares, 2000. M.G. Rowan and R. Linares , Fold-evolution matrices and axialsurface analysis of fault-bend folds: application to the Medina Anticline, Eastern Cordillera, Colombia. American Association of Petroleum Geologists Bulletin 846 (2000), pp. 741-764.

Sarmiento-Rojas and Nieuwland, 1999. L.F. Sarmiento-Rojas and D.A. Nieuwland , Map view restoration of transpressional thrust belts in the Northern Andes. Thrust Tectonics Conference, Royal Holloway, University of London, Abstracts (1999) p. 325 .

Sassi et al., 1993. W. Sassi, B. Colletta, P. Balé and T. Paquereau , Modelling of structural complexity in sedimentary basins: the role of pre-existing faults in thrust tectonics. Tectonophysics 226 (1993), pp. 97-112.

Schamel, 1991. S. Schamel , Middle and upper Magdalena basins. American Association of Petroleum Geologists Memoir 52 (1991), pp. 283-303.

Suárez, 1990. A.F. Suárez , The basement of the Eastern Cordillera, Colombia: an allochthonous terrane in northwestern South America. Journal of South American Earth Sciences 3 (1990), pp. 141-151. 
Suppe, 1983. J. Suppe , Geometry and kinematics of fault-bend folding. American Journal of Science 283 (1983), pp. 684-721.

Suppe, 1985. J. Suppe Principle of Structural Geology, Prentice-Hall, Englewood Cliffs, NJ (1985) $583 \mathrm{p}$.

Suppe and Medwedeff, 1990. J. Suppe and D.A. Medwedeff, Geometry and kinematics of fault-propagation folding. Eclogae Geologicae Helvetiae 83 (1990), pp. 409-454.

Sylvester, 1988. A.G. Sylvester, Strike-slip faults. Geological Society of American Bulletin 100 (1988), pp. 1666-1703.

Taboada et al., 2000. A. Taboada, L.A. Rivera, A. Fuenzalida, A. Cisternas, H. Philip, H. Bijwaard, J. Olaya and C. Rivera , Geodynamics of the Northern Andes: subductions and intra-continental deformation (Colombia). Tectonics 195 (2000), pp. 787-813.

Trenkamp et al., 2001. R. Trenkamp, J.N. Kellogg, J.T. Freymueller and H. Mora , Wide plate margin deformation, southern Central America and northwestern South America, CASA GPS observations. Revision for Journal of South American Earth Sciences (2001).

Ulloa et al., 1975. Ulloa, C.E., Camacho, R., Ecsobar, R., 1975. Mapa geológico del cuadrángulo K-12, Guateque. Ingeominas, scale 1:1 000 000, 1 sheet.

Ulloa and Rodríguez, 1979. C.E. Ulloa and E. Rodríguez , Geología del cuandrángulo K-12, Guateque. Boletín de Geología del Ingeominas Bogotá 221 (1979), pp. 3-55.

Vergara and Rodríguez, 1997. L.E. Vergara and G. Rodríguez , The Upper Cretaceous and Lower Paleocene of the Eastern Bogota Plateau and Llanos Thustbelt, Colombia: alternative appraisal to the nomenclature and sequence stratigraphy. Geología Colombiana 22 (1997), pp. 51-79.

Villamil et al., 1997. T. Villamil, P. Restrepo and K. Svela , Paleocene-Miocene paleogeographic evolution of Colombia. Proceedings, VI Simposio Bolivariano, Exploracion Petrolera en las cuencas subandinas, Cartagena, Colombia, September 1997 vol. 1, Asociación Colombiana de Geólogos y Geofísicos del Petróleo (1997) pp. 275-287 .

Villamil et al., 1998. T. Villamil, P. Restrepo and K. Svela , Campanian-Oligocene depocenter evolution and tectonostratigraphic development of Northwestern South America. AAPG International Conference and Exhibition, Rio de Janeiro, Brazil, November 1998 (1998) pp. 90-91 . 